\title{
Book Reviews/Boekbesprekings
}

\section{Borderstrike! \\ South Africa into Angola by Willem Steenkamp}

'Rifle and machinegun fire clattered in all directions; the deep-throated bark of the AA guns mingled with the thump of $90 \mathrm{~mm}$ guns and sullen explosions as Swapo dumps went up. Clouds of smoke and dust cloaked the groups of vehicles wheeling and circling around and through the patches of bush; the bodies of dead insurgents lay everywhere.'

When South African air and ground forces burst over the South West African-Angolan border in May 1978 it was a clear indication that the insurgency war had reached a completely new stage.

This first operation codenamed 'Reindeer', inaugurated the new South African policy of launching attacks into the neighbouring states which harboured insurgents intent on anti-South African actions.

Reindeer was a 'first' in many respects. Apart from being the first crossborder strike, it also featured the first true airborne attack ever carried out by the South African Defence Force. It also marked South Africa's entry into modern semiconventional warfare. It was also the first occasion on which South African troops clashed with the regular troops of the host country; a phenomenon that has occurred with ever greater frequency in Revenge and Sceptic, the operations which followed Reindeer.

These operations have aroused great ire worldwide, particularly in Africa. Damned by many as naked aggression by the 'White fascists', and acclaimed within South Africa in glowing and emotional terms, the true nature of these operations have become very much obscured. It is the purpose of the author to provide a reasonably accurate account of at least three of these operations.

In this respect Steenkamp is quite successful in telling the story of ordinary men involved in bitter fighting. With vivid descriptions he succeeds in illustrating how, as in all wars the most careful planning can go awry through the dynamics of war, and how desperate situations could be retrieved by men capable of thinking clearly under difficult and most dangerous conditions.
The author acknowledges that this book cannot be classed as a military history, for it does not present a full account of the operations. However, considering how little official South Africanorigin material is available and the almost noneexistence of Swapo sources, a satisfactory account has been provided.

It does, however, include a good deal of material that has never been made known before, and the personal recollections of some of the participants provide the reader with some insight as to what it was like to be there.

Borderstrike! will be especially worthwhile for those who have a keen interest in this hitherto unknown war on which very little has so far been published.

Lt D. Conradie

Paul C. Venter: Tussen Tiers: S.A. Oorlogshelde. Folio-uitgewers, Pretoria, 1983, 111 pp.

Hierdie boek bestaan uit ' $n$ twaalftal ware verhale waarin Paul C. Venter die heldedade van verskeie Suid-Afrikaanse oorlogshelde uit die twee Wêreldoorloë, die Koreaanse oorlog en die huidige terroristeoorlog op 'n gedramatiseerde wyse uitbeeld. Die boek is nie bedoel om 'n stuk wetenskaplike geskiedskrywing te wees nie en bring derhalwe, soos die skrywer self in sy voorwoord sê, nie juis nuwe feite aan die lig nie. Die skrywer slaag egter baie goed daarin om sy hoofdoel met die boek, naamlik om die leser bewus te maak van die menslike drama agter hierdie verhale van selfopoffering, durf en heldemoed, te bereik.

Sy goedversorgde styl en spannende, onderhoudende verteltrant boei die leser deurgaans en maak die boek besonder leesbaar, sodat dit wye byval onder die algemene publiek behoort te vind. 'n Punt van kritiek is dat die skrywer nie altyd die aanvaarbare militêre terme gebruik nie en byvoorbeeld praat van "Eskader 60" in plaas van "60 Eskader" en van "pelotonne" in plaas van "pelotons." Verder word die verhale nie in alle gevalle duidelik in die breër raamwerk van die betrokke oorlog gelokaliseer nie, terwyl die spesifieke eenheid waarin 'n persoon gedien het toe hy sy heldedaad verrig het, nie altyd vermeld word nie. In militêre kringe is ' $n$ heldedaad immers baie meer betekenisvol wanneer dit met ' $n$ bepaalde eenheid in verband gebring word.

Maj G.E. Visser 